\title{
IFRS, Accounting Standards and Business
}

\author{
Prof Assoc Ylber Bezo \\ College University of Business Tirana
}

\begin{abstract}
An accounting standard is a standardized guiding principle that determines the policies and practices of financial accounting. Accounting standards not only improve the transparency of financial reporting but also facilitates financial accountability.IFRS Standards are set by the International Accounting Standards Board (Board) and are used primarily by publicly accountable companies - those listed on a stock exchange and by financial institutions, such as banks. Authoritative interpretations of the Standards, which provide further guidance on how to apply them, are developed by the IFRS Interpretations Committee and called IFRIC Interpretations. The International Accounting Standards (IAS) constitute a single set of high-quality accounting standards, which help in the preparation of consolidated financial statements, including the balance sheet, income statement, statement of changes in the financial position, cash flow statement and explanatory notes. This paper is a theoretical view about the accounting standards .
\end{abstract}

Keywords : International standards, accounting standards, business account etc.

DOI: $10.7176 / \mathrm{RJFA} / 12-2-07$

Publication date: January $31^{\text {st }} 2021$

\section{The IFRS for SMEs}

The IFRS for SMEs Standard reflects five types of simplifications from full IFRS Standards:

- $\quad$ some topics in full IFRS Standards are omitted because they are not relevant to typical SMEs;

- $\quad$ some accounting policy options in full IFRS Standards are not allowed because a more simplified method is available to SMEs;

- many of the recognition and measurement principles that are in full IFRS Standards have been simplified;

- $\quad$ substantially fewer disclosures are required; and

- the text of full IFRS Standards has been redrafted in 'plain English' for easier understandability and translation.

- Accounting standards are authoritative standards for financial reporting and are the primary source of generally accepted accounting principles (GAAP).

- Accounting standards specify how transactions and other events are to be recognized, measured, presented and disclosed in financial statements. Their objective is to provide financial information to investors, lenders, creditors, contributors, and others that is useful in making decisions about providing resources to the entity.

\section{The Role of Accounting in International Business}

The purpose of accounting is to communicate the organization's financial position to company managers, investors, banks, and the government. Accounting standards provide a system of rules and principles that prescribe the format and content of financial statements. Through this consistent reporting, a firm's managers and investors can assess the financial health of the firm. Accounting standards cover topics such as how to account for inventories, depreciation, research and development costs, income taxes, investments, intangible assets, and employee benefits. Investors and banks use these financial statements to determine whether to invest in or loan capital to the firm, while governments use the statements to ensure that the companies are paying their fair share of taxes.

As countries developed different cultures, languages, and social and economic traditions, they developed different accounting practices as well. In an increasingly globalized world, however, these differences are not optimal for the smooth functioning of international business.

\section{The Emergence of New International Accounting Standards}

The International Accounting Standards Board (IASB) is the major entity proposing international standards of accounting. Originally formed in 1973 as the International Accounting Standards Committee (IASC) and renamed the International Accounting Standards Board in 2001, the IASB is an independent agency that develops accounting standards known as international financial reporting standards (IFRS)."History," International Accounting Standards Board, accessed November 26, 2010, http://www.ifrs.org/Home.htm.

The IASB is composed of fifteen representatives from professional accounting firms from many countries. "About the IFRS Foundation and the IASB," IFRS Foundation. These board members formulate the international reporting standards. For a standard to be approved, 75 percent of the board members must agree. Often, getting 
agreement is difficult given the social, economic, legal, and cultural differences among countries. As a result, most IASB statements provide two acceptable alternatives. Two alternatives aren't as solid or straightforward as one, but it's better than having a dozen different options.

The United States doesn't mandate using the IFRS. Instead, the United States has the Financial Accounting Standards Board (FASB), which issues standards known as generally accepted accounting principles (GAAP). The US currently mandates following GAAP. However, the FASB and IASB are working on harmonizing the accounting standards; many IASB standards are similar to FASB ones. The United States is moving toward adopting the IFRS but hasn't committed to a specific time frame[4].

e primary reason for adopting one standard internationally is that if different accounting standards are used, it's difficult for investors or lenders to compare the financial health of two companies. In addition, if a single international standard is used, multinational firms won't have to prepare different reports for the different countries in which they operate.

Accounting standards can be complex; and this makes modification of standards difficult. In addition, differing practices among various nations add to the complications of a unified accounting format. For example, in the United States and Great Britain, individual investors provide a substantial source of capital to companies, so accounting rules are designed to help individual investors.

In contrast, the tradition in Switzerland, Germany, and Japan is for companies to rely more on banks for funding. Companies in these countries have a tighter relationship with banks. This means that less information is disclosed to the public. It also results in accounting rules that value assets conservatively to protect a bank's investment. In other countries, the government steps in to make loans or invest in companies whose activities are in the "national interest."

Finally, accounting rules in China follow neither IFRS nor GAAP, which makes it hard for investors to gauge the true value of a company.

4.Characteristics of International Accounting Standards and Their Implications for International Business On one hand, having to adhere to GAAP rules as well as IFRS rules creates extra labor and paperwork for multinational firms. For example, a US company seeking to raise funds in Germany has to prepare a financial report according to IFRS accounting rules as well as US GAAP rules. Further problems arise when different country accounting rules make the financial statements look different. If the same transaction is accounted for in different ways based on different country accounting rules, the comparability of financial reports is undermined.

In some instances, the differences between US GAAP rules and IFRS are significant. For example, the lastin, first-out (LIFO) accounting method is allowed by GAAP but banned by IFRS. Some firms, such as aluminum company Alcoa, receive a tax benefit from using the LIFO method. If IFRS is mandated for all US companies, firms like Alcoa may need to make significant cash-tax payments. This is why US adoption of IFRS is taking time, and why the FASB and IASB are working hard to harmonize the standards[5].

On the positive side, other companies, like IBM, may gain greater efficiencies and stronger controls from a move to IFRS. For example, converting to IFRS would make it possible for IBM to create a globally shared service center for accounting, rather than having accounting departments in different regions.

US adoption of the IASB's global accounting standards would be useful to big multinational companies. Tyco International, for example, is the parent of 1,200 legal entities, 900 of them outside the United States. For Tyco, having to follow only IFRS rules would be positive, because it would enable Tyco to prepare financials on the same basis worldwide and to more freely move accounting staff from country to country and business to business. Nonetheless, given Tyco's massive network of information systems, making the switch would still be "a tremendous amount of work," according to John Davidson, the company's controller and chief accounting officer[6].

Some smaller public companies, however, would see only costs from a move to IFRS. Davey Tree Expert Company, for example, which only does business in the United States and Canada, sees no benefits. Because the company is unlikely to ever list on any national exchange, the argument that unified standards would allow comparability of financials has no value.

However, the IASB issued a specific standard for reporting by SMEs. From research, it was concluded that the majority of the economic entities in Albania were small and medium enterprises. Albania tended towards complying with the European Commission Directives because it aspired to join the EU; and because several overwhelming changes would exist for the accountants in Albania to completely change the financial reporting platform only five years after it had initially been introduced (and grasped with difficulties by these professionals).

\section{Conclusions}

Accounting standards are very important especially for international companies that have their activity with international company. Very good standards of accounting make different with states and accounting principes 
An accounting standard is a common set of principles, standards and procedures that define the basis of financial accounting policies and practices. ... In the United States, the Generally Accepted Accounting Principles form the set of accounting standards widely accepted for preparing financial statements. In the same time in all the states accounting standards are a key instrument for business companies.

\section{References}

IFRS standards and IFRIC interpretation. https://www.ifrs.org/issued-standards/ IFRS for SME standards . https://www.ifrs.org/issued-standards/ifrs-for-smes/

International Accounting Standards https://saylordotorg.github.io/text_international-business/s19-01international-accounting-stand.html

General Accepting Accounting principles https://2012books.lardbucket.org/books/.

IFRS AND Accounting International Standards. https://www.accounting.com/resources/gaap/

Arowomole, K. A. (2000). Modern Business Management (Theory and Practice), (1st Edition). Sango-Ota, Ogun State: Ade- Oluyinka Commercial Press (Chapter 132).

Darren, L. \& Conrad, L. (2009). Entrepreneurship and Small Business management in the Hospitality Industry. Jordan Hill, UK: Elsevier Linacre House.

Basic Principles Accounting.https://www.ifrs.org/issued-standards/ 